\title{
第 32 回
}

\section{専 門 医 認 定 試 験 問 題}

\section{問題番号 [1]}

\section{症 例: 79歳の男性 \\ 主 訴：難聴}

現病歴：約10年前から徐々に聞こえにくさを自覚した.

最近，家族にも指摘されるようになった。

検査所見 : 純音聴力検査結果（図 1 ）を示す.

経 過：補聴器装用を钦め, 両耳に耳掛け型補聴器を購

入したが, 補聴器の効果に満足していない。補聴器装

用・非装用時の音場での検査結果（図 2，3）を示

す.
Q1. 500, 1, 000, 2, $000 \mathrm{~Hz}$ のファンクショナルゲイン を求めよ。

Q2. 補聴器の効果に満足していない理由を述べよ.

Q3. 本例に対する補聴器フィッティングの留意点を述 ベよ.

問題 1

周波数 $(\mathrm{Hz})$

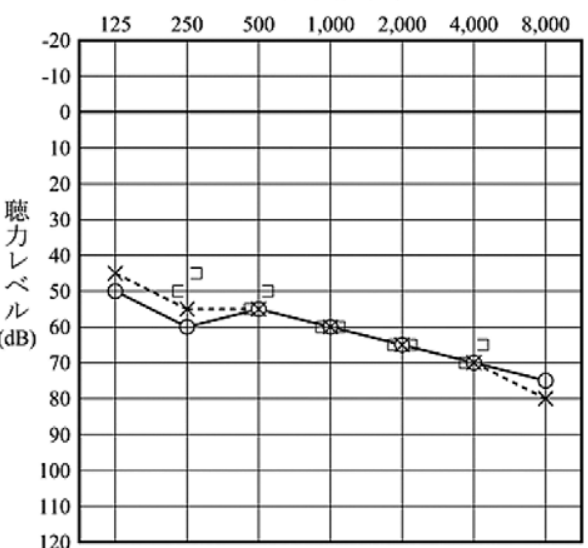

図 2

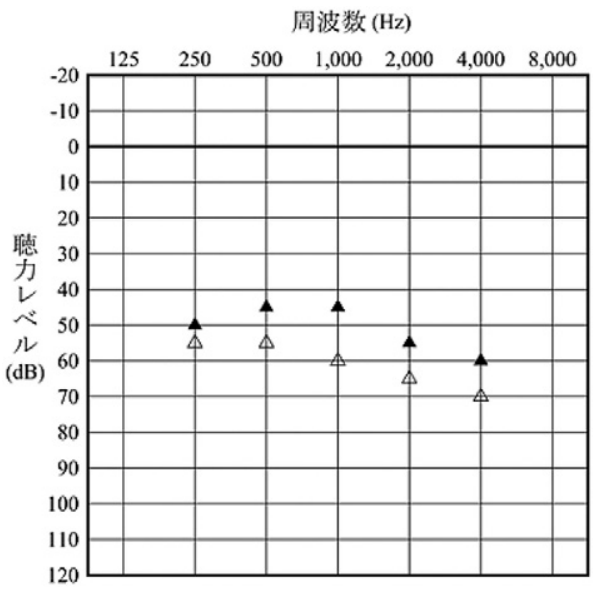

図 3

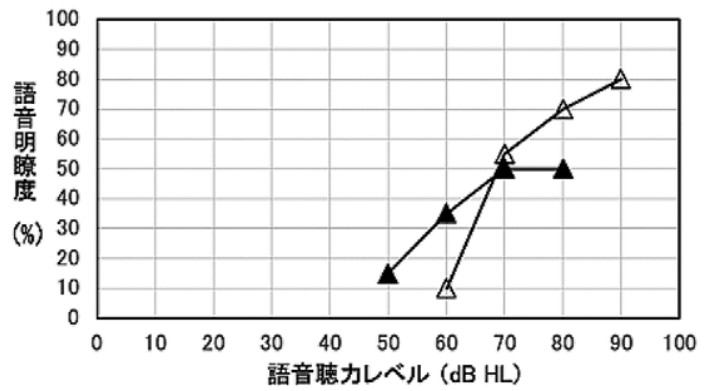

補聴器非装用時 : $\triangle$ 


\section{問題番号 [2]}

\section{症 例：20歳の女性 \\ 主 訴：両側の難聴}

既往歴: 糖尿病, 一過性脳虚血発作

現病歴：小学生のころからの難聴を主訴に受診した。鼓 膜所見 (図 1 ), 眼所見 (図 2 ), 純音聴力検査結果 （図 3），側頭骨 CT（図4）を示す.
Q1. 問診で追加して確認すべき事項をあげよ。

Q2. 鼓膜所見，眼所見，CT所見を述べよ。

Q3. 難聴を来す病態と今後の対応を述べよ.

問題 2
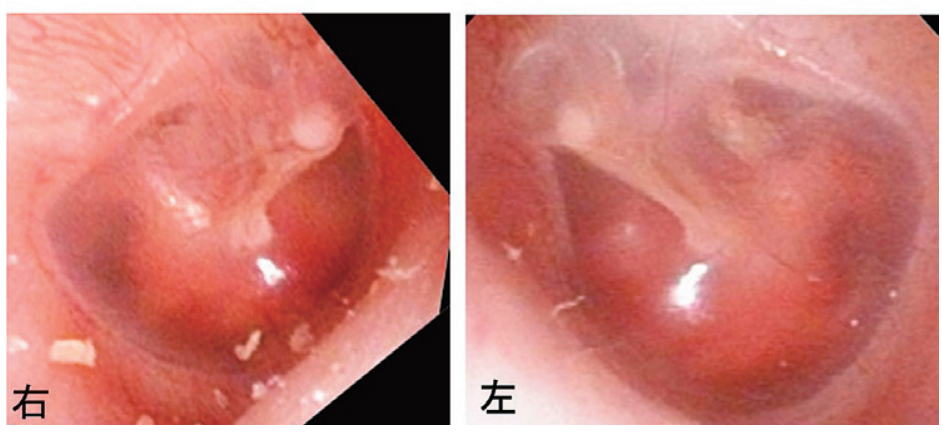

図 1

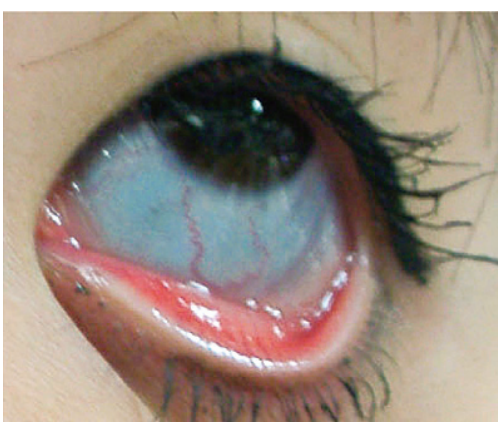

図 2

周波数 $(\mathrm{Hz})$

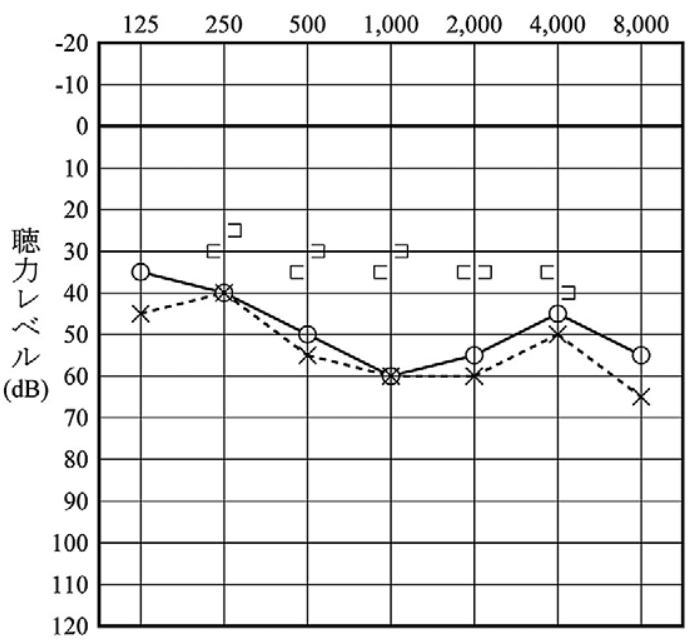

図 3

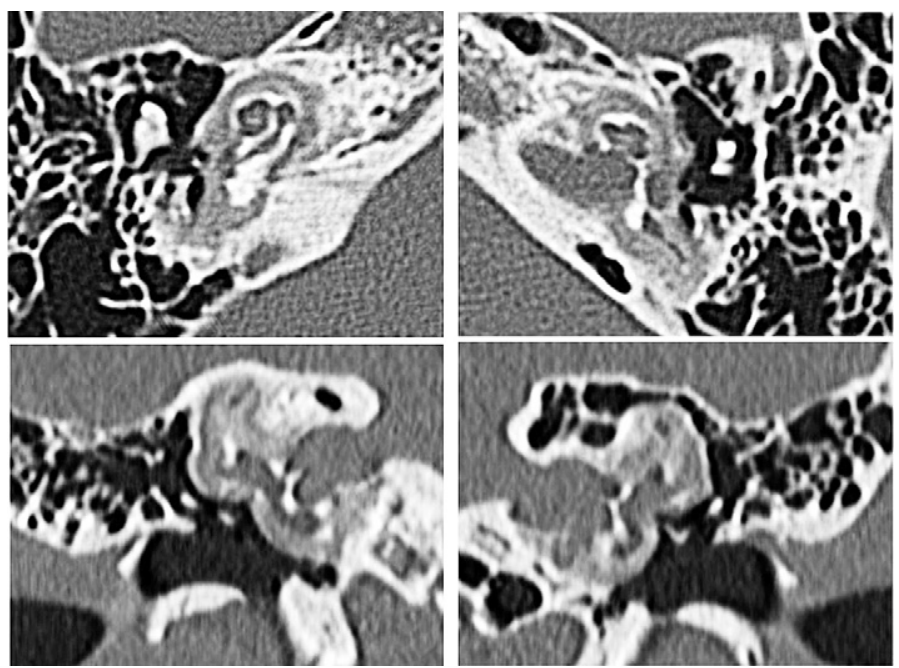

図 4 


\section{問題番号 [3]}

症 例: 67歳の男性

現病歴：急に振り向いたときに左頸部から肩にかけて痛 みが走った。 その直後よりめまいを自覚し救急病院を 受診. 頭部 CT, 胸部エックス線写真, 心電図に異常 なく，そのまま帰宅した。翌日になってもめまいがお さまらないため受診した。

検査所見：体幹失調を認め, 立位保持困難であった。右 向きの水平性眼振を認めた。純音聴力検査結果 (図 1 ), 頭部 MRA および MRI T2 強調画像（図 2 ） を示す。
Q1. 頭部 MRA および MRI T2 強調画像の所見を述べ よ.

Q2. めまいと難聴の病態を述べよ.

Q3. めまいの急性期と慢性期における対応を述べよ.

問題 3

図 1

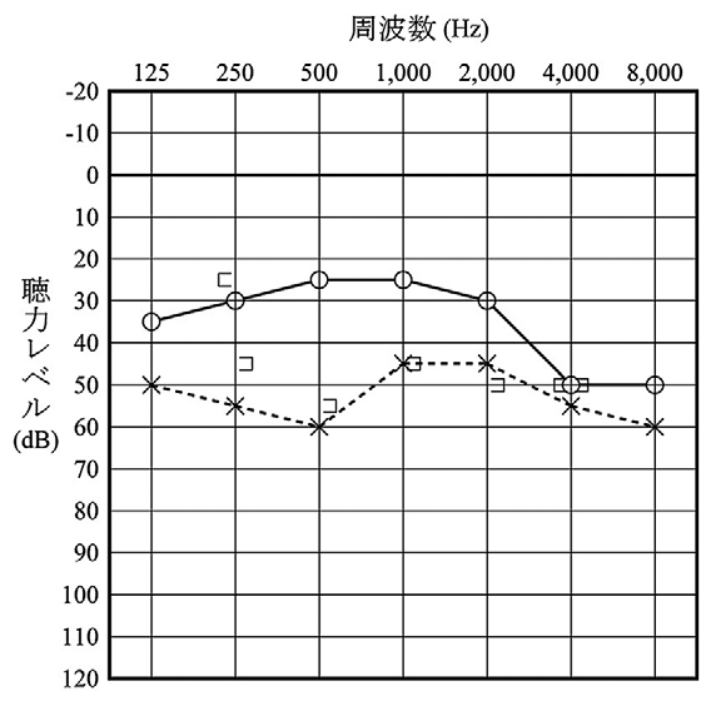

MRA

困 2

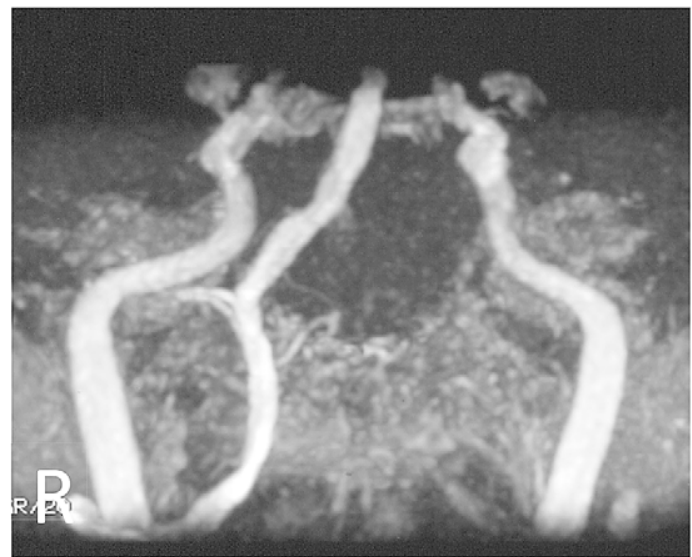

T2 強調画像

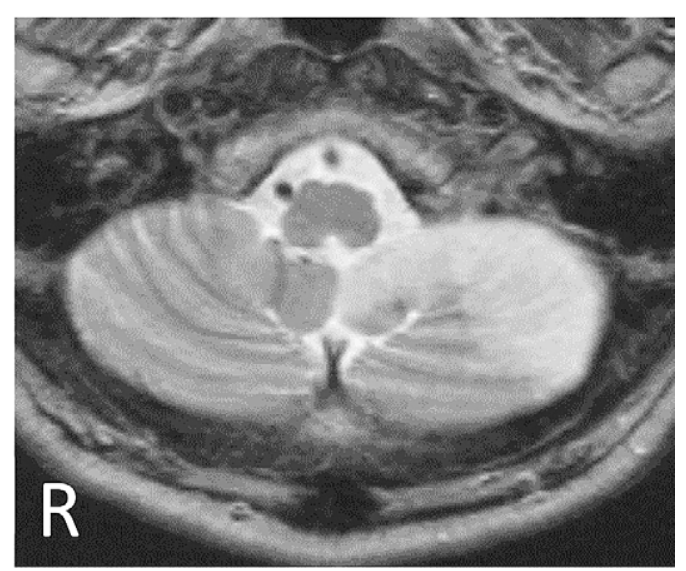




\section{問題番号 [4]}

症 例: 46歳の女性

主 訴：鼻漏, 嗅覚低下, 耳漏, 難聴

既往歴：アレルギー性鼻炎，気管支喘息

現病歴：40歳より鼻漏, 嗅覚低下, 耳漏, 難聴を自覚 し，近医にて保存的治療を受けるも寛解増悪を繰り返 していた．半年前から嗅覚障害が悪化した。

現 症：鼻腔内視鏡所見では両側中鼻道および嗅裂に鼻 茸を認めた。副鼻腔 CT (図 1 ), 耳漏の HE および Papanicolaou染色所見（図 2 ), 鼻茸の病理組織所見 (400倍視野)（図 3 ）を示す。末梢血好酸球は $14.5 \%$, 血清総 IgE は $527 \mathrm{IU} / \mathrm{mL}$ であった.
Q1. 副鼻腔 CT, 耳漏の HE および Papanicolaou 染色 の所見を述べよ.

Q2. 考えられる疾患を挙げよ.

Q3. 治療方針について述べよ.

問題 4

図 1

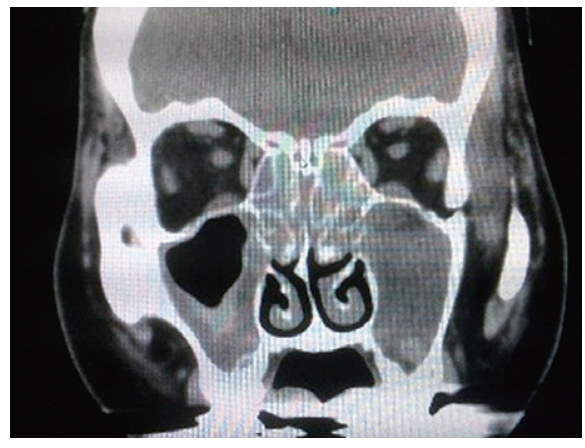

困 2
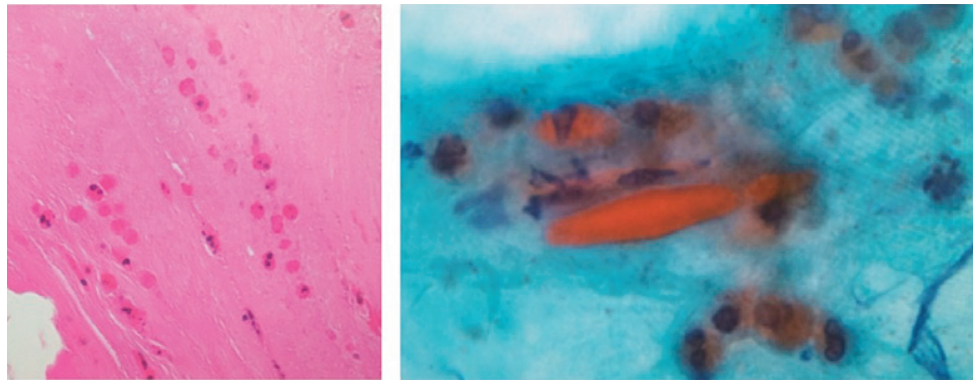

図 3

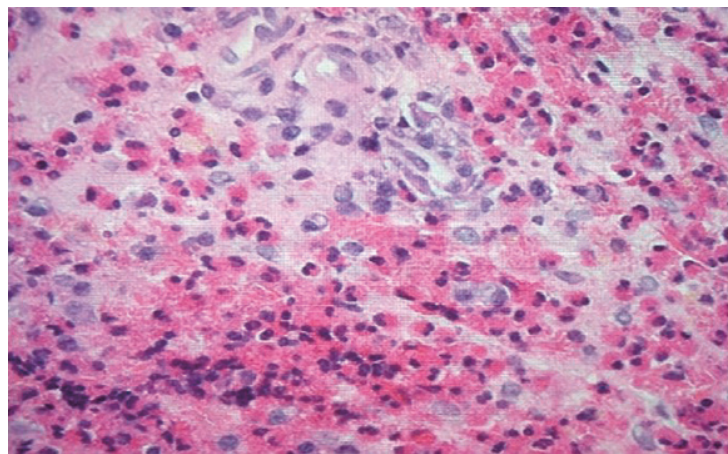




\section{問題番号 [5]}

\author{
症 例：41歳の男性 \\ 主 訴：いびき, 日中傾眠 \\ 現 症：身長 $165 \mathrm{~cm}$, 体重 $87 \mathrm{~kg}$
}

検査結果：終夜睡眠ポリグラフ（PSG）検査にて AHI $37 / \mathrm{h}, 3 \%$ 酸素飽和度低下指数 $35.8 / \mathrm{h}$, 覚醒反応指 数 $45.6 / \mathrm{h}, \%$ \%睡眠 $15.2 \%, \%$ 深睡眠 $4.6 \%$ の結果 であった.PSGの代表的な 5 分間生波形（図 1 ），お よび口腔咽頭の所見（図 2 ）を示す.
Q1. PSGの所見を述べよ.

Q2. 今後の方針を決定するために必要な検査を挙げよ.

Q3. 指導と治療法を述べよ.

問題 5

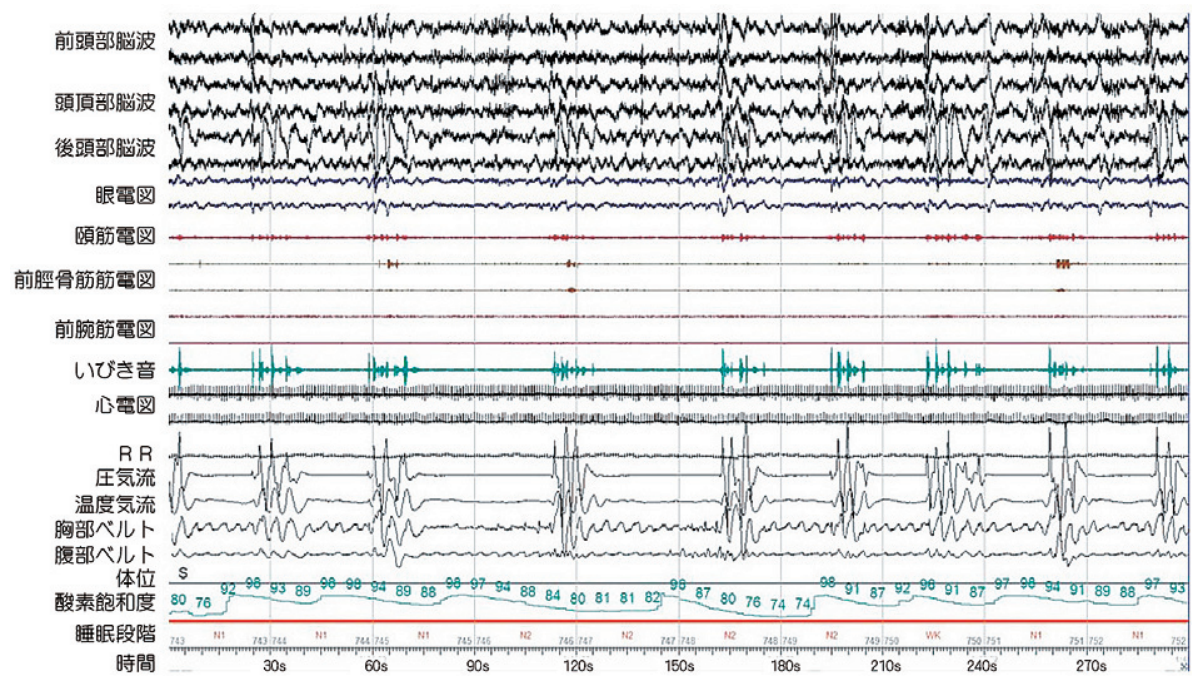

図 1

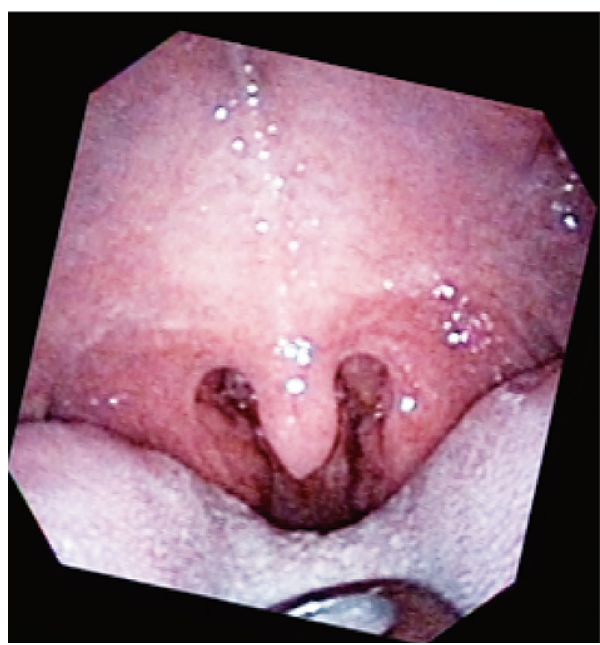

図 2 


\section{問題番号 [6 ]}

症 例: 51歳の男性

現病歴： 2 年前に交通事故による急性硬膜下血腫，脳挫 傷を来し，気道管理目的に気管切開を受けた。発話障 害, 嚥下障害, 左片麻痺に対してリハビリテーション を継続していたが, 肺炎を繰り返すため車椅子で受診 した。気管切開孔にはカフなしカニューレを挿入され ており，気管内の分泌物を自己喀出できずに頻回の吸 引が必要である．意思疎通は文字盤で行っている．胃 瘦による栄養管理を受けている。喉頭所見（図 1 ）お よび気管切開孔から観察した声門下の所見（図 2）を 示す.

\section{問題 6}

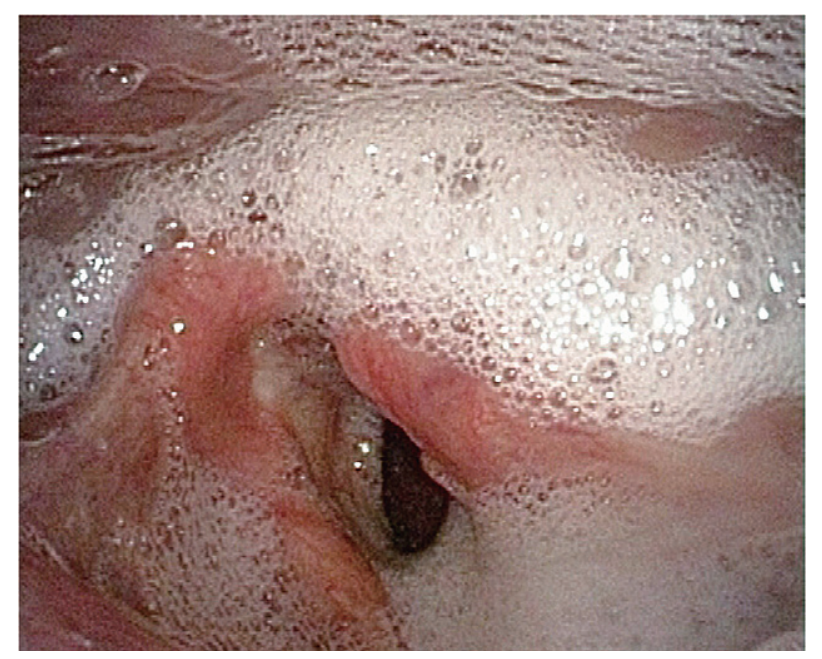

図 1
Q1. 内視鏡検査所見と病態を述べよ.

Q2. 肺炎の反復を防止するための保存的治療を述べよ.

Q3. 外科的治療を行う場合の術式を複数あげ，その利 点・欠点を述べよ.

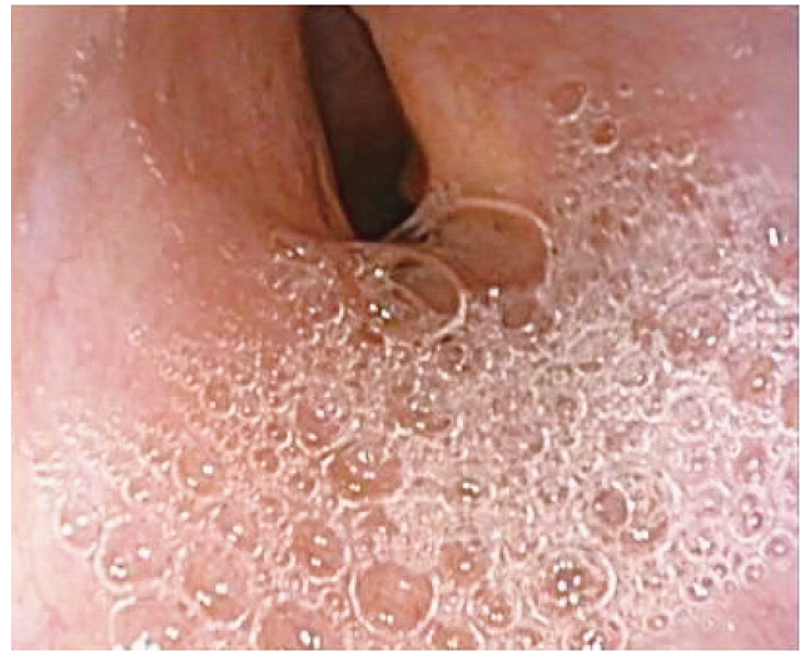

図 2 


\section{問題番号 [7]}

\section{症 例 : 82歳の男性 \\ 主 訴: 左頸部腫脹, 圧痛, 発熱}

現病歴：数日前から左頸部腫脹, 圧痛, および $37^{\circ} \mathrm{C}$ 台の 発熱がある。

現 症：左側頸部を中心に圧痛と熱感を伴うびまん性の 腫脹を認める。

検査所見：赤血球 $435 / \mu 1$, 白血球 $13,910 / \mu 1$, 血 小板 19.8 万 $/ \mu 1$, 好中球 $78.6 \%$, リンパ球 $9.1 \%$, 単球 $9.3 \%, \mathrm{CRP} 20.1 \mathrm{mg} / \mathrm{dl}$. 喉頭内視鏡所見（図 1 ），頸 部造影 CT（図 2 ）を示す.
Q1. 頸部造影 CT の所見を述べよ.

Q2. 鑑別すべき疾患を挙げよ.

Q3. 治療の要点を記すとともに，注意すべき合併症を 挙げよ。

\section{問題 7}

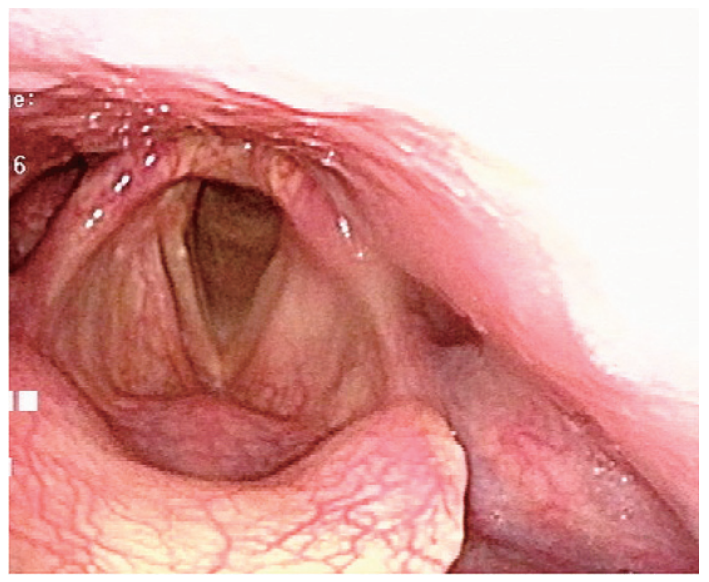

図 1
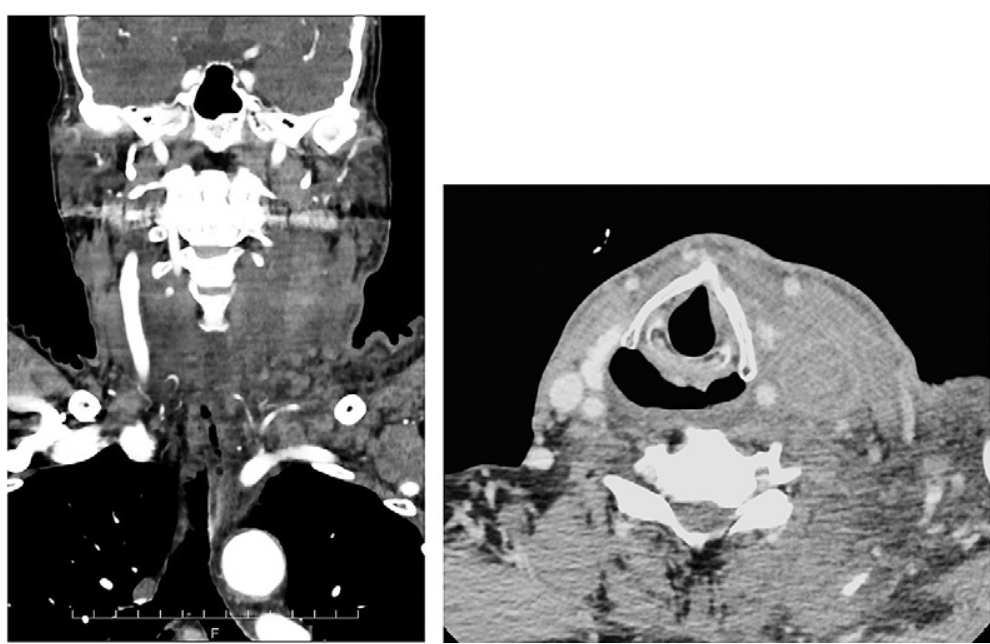

図 2 


\section{問題番号 [8]}

症 例: 72歳の男性

主 訴：3力月前より咽頭違和感を自覚していた。喫煙 歴は20本/日を30年間, 日本酒 1 ～ 2 合を毎日飲酒.

現 症: 喉頭内視鏡所見（図 1) および頸部 MRI（T2 強調， $\mathrm{T} 1$ 強調脂肪抑制ガドリニウム造影）（図 2 ）, 生検の病理組織所見（図 3 ) を示す。声帯麻痺はな w.
Q1. 内視鏡所見, MRI 所見, 病理組織所見を述べよ.

Q2. 治療開始前に行うべき検査とその目的について述 べよ.

Q3. 治療方針について述べよ.

問題 8

図 1

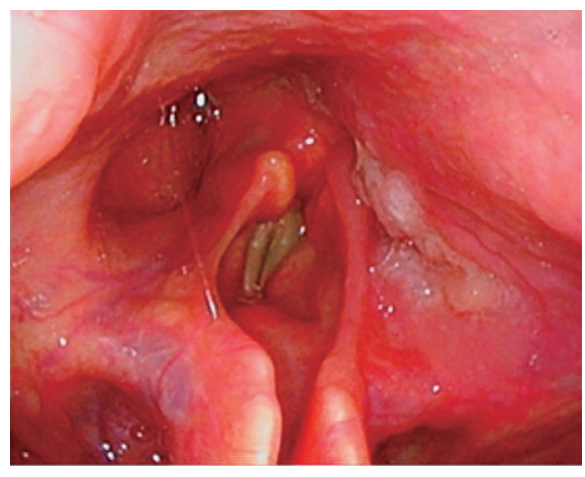

図 2
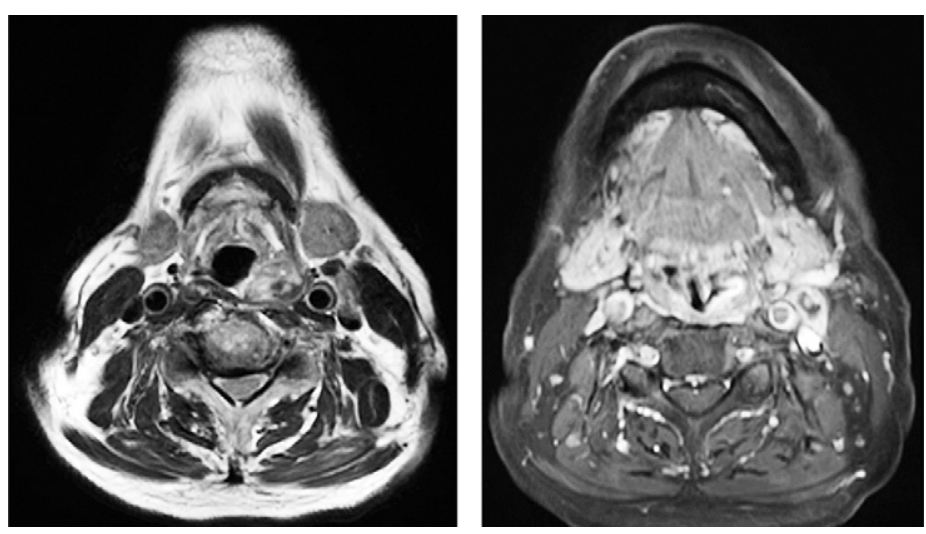

図 3

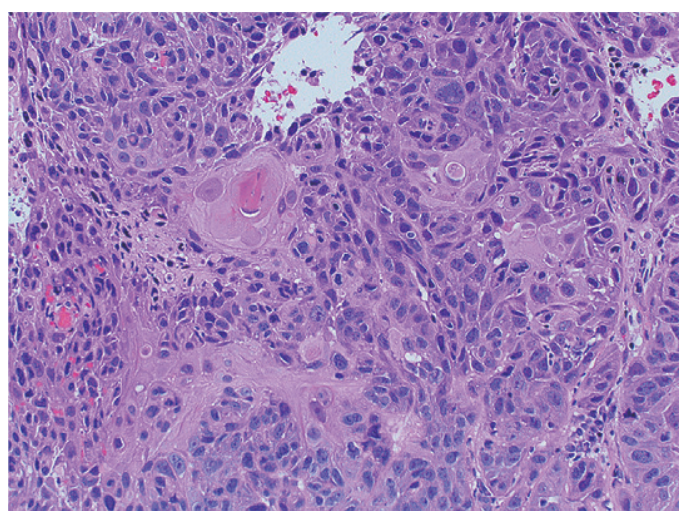




\section{第32回専門医認定試験問題 キーワード}

\section{問題番号 [1]}

作問のねらい

補聴器適合検査は耳鼻科医の担う重要な役割であり, 本問では適合検査の結果より，補聴器および患者の状態 を把握するための基本的な知識を問うた.

キーワード

Q1 ファンクショナルゲイン $=$ 裸耳域值一装用域值

Q2 利得不足, 装用時最高明暸度の低下

Q3 本例ではリクルートメント現象ではなく過度の圧 縮, ダイナミックレンジ拡大が必要

\section{問題番号 [2]}

作問のねらい

典型的な耳内および眼球所見，聴力像，側頭骨 CT 画 像から van der Hoeve 症候群の診断と対応を問うた。多 くが常染色体優性遺伝形式をとり，骨形成不全による骨 折の既往を伴う。初期にはアブミ骨固着による伝音難聴 が主だが，進行すると内耳が障害され混合性難聴を呈 し，高度難聴に至る例もある。

キーワード

Q1 骨形成不全に伴う病的骨折, 常染色体優性遺伝

Q2 岬角の充血, 強膜の色調, 骨迷路周囲の脱灰

Q3 補聴器, アブミ骨手術, 人工聴覚器

\section{問題番号 [3]}

作問のねらい

頸部痛に引き続いて体幹失調を起こす中枢疾患（椎骨 動脈解離）の知識を問うた。 AICA 症候群では潅流領域 の小脳梗塞だけでなく内耳動脈の血流障害から末梢障害 による難聴や眼振を来し得る.

キーワード

Q1 左椎骨動脈, 左小脳半球, 高信号

Q2 椎骨動脈解離, AICA 症候群

Q3 脳神経内科, 前庭リハビリテーション

\section{問題番号 [4]}

作問のねらい

アレルギー性鼻炎，気管支喘息の既往があり，好酸球 性副鼻腔炎，好酸球性中耳炎のほか，アレルギー性真菌 性副鼻腔炎, 酸球性多発血管炎性肉芽腫症 (EGPA), 好酸球性増多症を念頭に置いて診断, 治療する知識を問 う.

キーワード

Q1 篩骨洞優位, 好酸球浸潤, シャルコーライデン結晶

Q2 好酸球性副鼻腔炎やアレルギー性真菌性副鼻腔炎, 好酸球性中耳炎, EGPA や好酸球性増多症

Q3 好酸球性副鼻腔炎の治療（易再発と指定難病の説明 をして内視鏡下鼻副鼻腔手術・鼻噴霧用ステロイド 薬と短期間ステロイド内服・抗 IL-4 受容体 $\alpha$ サブ ユニット抗体製剂), 好酸球性中耳炎の治療, 気管 支喘息とアレルギー性鼻炎の治療

\section{問題番号 [5]}

作問のねらい

耳鼻咽喉科医にとって頻度の高い疾患である睡眠時無 呼吸症の対応について確認するともに，終夜睡眠ポリグ ラフ（PSG）の生データから閉塞性なのか中枢性なの か, また睡眠への影響について読み解く力を問うた. キーワード

Q1 気流停止, 胸腹部運動, 覚醒反応

Q2 鼻咽腔内視鏡, 鼻腔通気度, セファロメトリ（頭部 $\mathrm{X}$ 線規格撮影)

Q3 CPAP (持続気道陽圧療法), 口蓋扁桃摘出 - 軟口 蓋手術, 減量・生活習慣改善

\section{問題番号 $[6]$}

作問のねらい

䀻燕下内視鏡所見と既往から嚥下障害の病態を評価し, 適切な対応が行えるかを問うた。年齢から喉頭機能温存 が望まれるが，発話障害は高次機能障害を示唆してお り，回復困難な重症嚥下障害と考える。すでに喉頭機能 温存が困難であることを理解できるかが鍵である.

キーワード

Q1 唾液貯留, 誤嚥, 感覚運動障害 
Q2 カフ付きカニューレ, 吸引, 嚥下訓練

Q3 誤嚥防止手術, 発声不能, 負担軽減

\section{問題番号 [7]}

作問のねらい

(1) 病歴, 各種所見を正しく評価し, これを矛盾なく 統合して確定診断につなげることができる, (2)病態に 応じた治療を選択し, 想定される事態に備えて行動でき る，これら専門医に求められる基本的な実力を問う. キーワード

Q1 内頸静脈, リング状造影効果, 気道

Q2 内頸静脈, 頸部, 炎症

Q3 感染症, 塞栓症, 悪性腫瘍
問題番号 [8]

作問のねらい

下咽頭癌診断のプロセスと治療選択について理解を問 うた，各種検査所見を評価できるか，治療計画を行う上 で追加すべき検査を理解しているかを確認した.

キーワード

Q1 梨状陥凹, 頸部リンパ節腫大, 異型細胞増生と角化 傾向

Q2 上部消化管内視鏡, PET-CT, 血液検査（腎機能評 価など）

Q3 化学放射線治療, 咽喉頭摘出術, 姑息的治療

第32回専門医認定試験多肢選択問題解答

\begin{tabular}{|c|c|c|c|c|c|c|c|}
\hline 問題番号 & 正答肢 & 問題番号 & 正答肢 & 問題番号 & 正答肢 & 問題番号 & 正答肢 \\
\hline 1 & $a, b$ & 26 & $\mathrm{~d}$ & 51 & $\mathrm{~b}$ & 76 & $\mathrm{e}$ \\
\hline 2 & $\mathrm{a}$ & 27 & $a, d$ & 52 & e & 77 & e \\
\hline 3 & $\mathrm{~d}$ & 28 & $\mathrm{~b}$ & 53 & $\mathrm{e}$ & 78 & c \\
\hline 4 & c & 29 & $\mathrm{~d}$ & 54 & $\mathrm{a}$ & 79 & c \\
\hline 5 & $\mathrm{a}, \mathrm{c}, \mathrm{d}$ & 30 & e & 55 & $\mathrm{a}$ & 80 & $b, d$ \\
\hline 6 & b & 31 & $\mathrm{e}$ & 56 & d & 81 & d \\
\hline 7 & $\mathrm{~d}$ & 32 & $b, \quad c$ & 57 & d & 82 & $\mathrm{~d}$ \\
\hline 8 & e & 33 & $\mathrm{c}$ & 58 & $\mathrm{~b}, \mathrm{c}, \mathrm{e}$ & 83 & $\mathrm{~b}$ \\
\hline 9 & $\mathrm{c}$ & 34 & $\mathrm{~b}$ & 59 & a & 84 & $\mathrm{~d}$ \\
\hline 10 & $a, b$ & 35 & $\mathrm{a}, \mathrm{c}$ & 60 & $\mathrm{e}$ & 85 & $a, b$ \\
\hline 11 & $\mathrm{e}$ & 36 & $\mathrm{e}$ & 61 & $\mathrm{a}, \mathrm{c}$ & 86 & $c, e$ \\
\hline 12 & $\mathrm{~d}$ & 37 & $b, \quad d$ & 62 & $\mathrm{e}$ & 87 & $\mathrm{a}$ \\
\hline 13 & d & 38 & $\mathrm{c}$ & 63 & $\mathrm{~b}$ & 88 & $\mathrm{~b}$ \\
\hline 14 & $\mathrm{c}, \mathrm{d}, \mathrm{e}$ & 39 & $\mathrm{c}$ & 64 & e & 89 & $a, d$ \\
\hline 15 & b & 40 & $c, \quad d$ & 65 & $\mathrm{~b}$ & 90 & $\mathrm{~d}$ \\
\hline 16 & $\mathrm{~b}$ & 41 & d & 66 & e & 91 & $\mathrm{a}$ \\
\hline 17 & d & 42 & d & 67 & e & 92 & $a, c$ \\
\hline 18 & d & 43 & c & 68 & $\mathrm{~b}$ & 93 & $\mathrm{~d}$ \\
\hline 19 & a & 44 & b & 69 & d & 94 & $b, c$ \\
\hline 20 & d & 45 & $\mathrm{a}, \mathrm{c}$ & 70 & $\mathrm{a}, \mathrm{c}, \mathrm{d}$ & 95 & $\mathrm{~b}, \mathrm{e}$ \\
\hline 21 & $\mathrm{~b}, \mathrm{c}$ & 46 & $\mathrm{c}$ & 71 & b & 96 & c \\
\hline 22 & $\mathrm{c}$ & 47 & $\mathrm{~d}$ & 72 & $\mathrm{c}, \mathrm{d}, \mathrm{e}$ & 97 & $\mathrm{a}$ \\
\hline 23 & $\mathrm{a}, \mathrm{b}, \mathrm{d}$ & 48 & $\mathrm{~b}, \mathrm{e}$ & 73 & d & 98 & $\mathrm{~b}$ \\
\hline 24 & d & 49 & $\mathrm{c}$ & 74 & b & 99 & $\mathrm{e}$ \\
\hline 25 & e & 50 & $\mathrm{a}$ & 75 & $\mathrm{~b}, \quad \mathrm{c}$ & 100 & $a, \quad c$ \\
\hline
\end{tabular}

